papers be returned to the authors in order to reduce as far as possible the proceedings to those papers of real interest to all of the members of the Association. The Secretary was asked to return the papers thus set aside.

Chairman A. L. Melander: This concludes the convention. We stand adjourned to meet at San Francisco, Cal., next year.

Meeting adjourned.

E. C. VANDyke, Secretary protem.

\title{
PART II. PAPERS AND DISCUSSIONS
}

Morning Session, June 1\%, 1920, 10.80 p. m.

Chairman A. L. Melander: The regular papers for presentation and discussion will now be taken up. The first on the program is on "The Winterkilling of Codling Moth Larvæ."

\section{WINTERKILLING OF CODLING MOTH LARVE ${ }^{t}$}

By E. J. Newcomer, U. S. Bureau of Entomology, Yakima, Wash.

It is a common experience in the spring to find "winter-killed" codling moth larvæ. The writer, however, does not remember seeing any figures on the percentage of mortality resulting from different degrees of cold. Accurate figures could be secured only under controlled temperature conditions, but an opportunity has occurred recently of obtaining some interesting figures of mortality resulting from natural conditions.

In Washington State, temperatures far below the normal were experienced during December, 1919, ranging in the Yakima and Walla Walla valleys from $-14^{\circ}$ to $-36^{\circ} \mathrm{F}$. At Yakima, on December 9 and 10 , there was a snowstorm with some wind, almost of the character of a blizzard, the temperature for the two days ranging between $7^{\circ}$ and $16^{\circ} \mathrm{F}$. The storm cleared away on the $11 \mathrm{th}$, the minimum temperature being $0^{\circ}$. For the succeeding four days, the temperatures were as follows: ${ }^{2}$

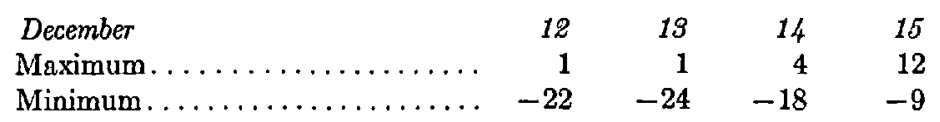

During this period there were from 4 to 18 inches of snow on the ground. After December 15, the weather warmed up gradually, and

1 Presented with permission of the Secretary of Agriculture.

${ }^{2}$ Figures taken from Climatological Data, U. S. Weather Bureau. 
for five or six days after the 20th, the temperature remained above freezing.

Examinations of larvæ were made during the period from December 23 to February 28. It was found that wherever the minimum temperature had been lower than $-25^{\circ}$, all larva, with no protection other than bark or burlap bands, were killed. At the Bureau of Entomology Laboratory in Yakima, the minimum temperature was $-25^{\circ}$, and several thousand larvæ wintering in pupation sticks all succumbed. In orchards within two or three miles of the laboratory, and on higher ground, where the minimum temperatures ranged from $-20^{\circ}$ to $-25^{\circ}$, 80-90 per cent of the larvæ were killed. On still higher ground, with minimum temperatures of $-15^{\circ}$ to $-20^{\circ}$, the mortality was approximately 70 per cent. Reports from the Wenatchee Valley, where the lowest temperature recorded was $-20^{\circ}$, placed the mortality at from 75-80 per cent. There was no opportunity of examining larvæ in situations where the minimum temperature was higher than $-14^{\circ}$. In all cases, these figures apply to the larvæ wintering above the snow line.

As the ground was frozen at the time of the earlier examinations, it was impossible to ascertain the condition of the large number of larvæ which winter under the surface of the soil. In February, however, examinations were made of the larvæ which spun their cocoons about the tree trunks an inch or two beneath the soil surface, where they were undoubtedly covered with snow during the cold weather. On February 28 , a banded orchard was examined near Zillah, Wash., where the temperature had dropped to $-24^{\circ}$, according to an unofficial record. The land was somewhat rolling, and it is probable that the drifting snow had accumulated in varying depths about different trees, as there was a marked variation in the condition of the larvæ found on the various trees. The mortality ranged from 100 per cent on some trees to as low as 66 per cent on others, with an average for 280 larvæ counted, of 76 per cent. One interesting fact noted was that frequently, on tearing away the burlap band, one or two live larvæ would be found in the midst of a number of dead ones. It seems impossible, in these cases, that the live larvæ had any more protection than the others. They must simply have had more vitality.

All these records were obtained in the arid section of Washington. It would be interesting to know whether temperatures such as were experienced in this section would produce a similar mortality in more humid regions, such as the coastal sections of Washington and Oregon, or parts of the eastern United States. 
Chairman A. L. Melander: The next paper is entitled, "Winterkilling of the San José Scale."

\section{WINTERKILLING OF THE SAN JOSÉ SCALE}

\section{By Anthony Spdler, Washington Slate College}

Since early in the spring there has been considerable evidence to lead the fruit grower to believe that the San Jose Scale had been killed in large numbers during the past winter. The usual method of scraping the bark of badly infested trees with a knife showed that the insects were not juicy as commonly found at this time, but that they were dry and came off readily.

In order to determine to what extent the scale had been killed, a thorough examination of their overwintering condition was made. Early in March the district horticulture inspectors sent in infested branches from a number of orchards in each of the fruit-growing sections of the state. This was followed a little later by a personal investigation in the field in which all of the fruit-growing sections were visited. Samples were cut from healthy trees in a number of orchards within a district. Every effort was made to secure material that was typical for the various localities visited. The material secured in this way was carefully examined. Thousands of individual insects were dissected off under a binocular and their condition noted. It was possible in this way to learn the per cent of San Jose Scale still alive. Following are the results obtained:

\begin{tabular}{|c|c|c|c|c|}
\hline Locality & Total & & & $\begin{array}{l}\text { Per } \\
\text { cent }\end{array}$ \\
\hline & Counted & Dead & Alive & Alive \\
\hline Clarkston. & 10,144 & 9,595 & 549 & 5.4 \\
\hline Walla Walla. & 12,816 & 12,388 & 428 & 3.2 \\
\hline Prosser $\ldots \ldots \ldots \ldots \ldots \ldots \ldots \ldots \ldots$ & 2,545 & 2,545 & $\mathbf{0}$ & 0 \\
\hline Yakima................... & 8,595 & 8,526 & 72 & 1.5 \\
\hline White Salmon. . . . . . . . . . . . & 2,093 & 1,729 & 364 & 17.8 \\
\hline Wenatchee. . . . . . . . . . . . . & 5,409 & 5,309 & 100 & 1.8 \\
\hline Spokane..................... & 2,485 & 2,013 & 472 & 19.2 \\
\hline
\end{tabular}

In contrast to the foregoing is the average per cent of winterkill of the San Jose Scale for the past ten years, not including the winter of 1919-20 for the following localities: Clarkston, 19 per cent; Walla Walla, 24 per cent; Yakima, 32 per cent and Wenatchee, 40 per cent.

The high percentage of winterkill of the scale might be explained in two ways. In the first place the winter started rather early. In October the temperature in the fruit-growing sections dropped as low as 12 to 14 degrees Fahrenheit. This was in all probability before the scale had gone into hibernation and before they were in a condition to 